\title{
Perancangan Desain Wisata untuk Pengembangan Potensi Alam Desa Jatisari
}

\author{
Imam Rofiki ${ }^{1}$, Chansa Nabilla Aura ${ }^{2}$, Ahmad Abtokhi ${ }^{3}$, Abdussakir ${ }^{4}$ \\ 1,2,3,4 Universitas Islam Negeri Maulana Malik Ibrahim Malang \\ Email: imam.rofiki@uin-malang.ac.id ${ }^{1}$, chansanabilla@gmail.com², \\ abtokhiuin@gmail.com ${ }^{3}$, sakir@mat.uin-malang.ac.id ${ }^{4}$ \\ *Corresponding author: imam.rofiki@uin-malang.ac.id ${ }^{1}$
}

\begin{abstract}
ABSTRAK
Upaya pengembangan potensi alam sangatlah penting untuk meningkatkan potensi wisata Desa Jatisari. Potensi wisata di Desa Jatisari adalah area petik buah, mini zoo, telaga, kolam pemancingan, dan kolam renang. Beberapa cara dilakukan untuk menjadikan Jatisari sebagai desa wisata. Tujuan kegiatan ini untuk mengembangkan potensi wisata yang dapat meningkatkan ekonomi masyarakat di Desa Jatisari Kecamatan Tajinan Kabupaten Malang. Metode pelaksanaan yang digunakan untuk kegiatan pengembangan wisata ini adalah survei lokasi wisata dan perancangan desain. Kegiatan ini berupa perancangan desain wisata dengan bentuk animasi. Pihak perangkat desa dan masyarakat memberikan respons positif terhadap produk rancangan. Hasil perancangan ini dapat dijadikan acuan untuk pembangunan selanjutnya secara bertahap.
\end{abstract}

Kata Kunci: perancangan desain; potensi alam; desa wisata.

\begin{abstract}
Efforts to develop natural potential are very important to increase the tourism potential of Jatisari Village. The tourism potential in Jatisari Village is the fruit picking area, mini zoo, lake, fishing pond and swimming pool. Several methods are used to make it a tourism village. The purpose of this activity was to develop tourism potential that can improve the economy of the community in the Jatisari Village, Tajinan District, Malang. The implementation method used for this tourism development activity was a survey of tourist sites and design construction. The activity was in the form of tourism design construction with an animation form. Village officials and the community responded positively to the product design. The results of this design can be used as a reference for further development gradually.
\end{abstract}

Keywords: design construction; natural potential; tourism village. 


\section{PENDAHULUAN}

Pengembangan kawasan

wisata berkaitan dengan kekayaan alam yang terdapat di daerah tujuan wisata dan hasil rancangannya membuat daya tarik agar orangorang mau datang berkunjung ke tempat yang sudah didesain. Pengembangan kawasan wisata merupakan alternatif yang diharapkan mampu mendorong baik potensi ekonomi maupun upaya pelestarian. Pengembangan kawasan wisata dilakukan dengan menata kembali berbagai potensi dan kekayaan alam dan hayati secara terpadu.

Desa wisata adalah sebuah kawasan pedesaan yang memiliki beberapa karakteristik khusus untuk menjadi daerah tujuan wisata (Atmoko, 2014; Ratnaningtyas, \& Widyasmoro, 2016; Zakaria \& Suprihardjo, 2014; Wiyatiningsih, Harijani, Santoso, \& Wijaya, 2020). Beberapa pengabdian masyarakat terkait desa wisata sudah banyak dilakukan. Fikri \& Septiawan (2020) melakukan kegiatan pngembangan wisata di Desa Kurau Barat. Raharja, Marbun, \& Chan, (2019) membuat strategi pengembangan pariwisata perdesaan di Lebak Muncang, Bandung. Saepudin, Budiono, \& Halimah (2019) mengembangkan desa wisata pendidikan di Desa Cibodas Kabupaten Bandung Barat. Sumarto \& Dwiantara (2020) melibatkan masyarakat dalam tata kelola pariwisata di Kampung Wisata Dewo Bronto Yogyakarta.
Purwanto (2020) memberdayakan masyarakat dalam pengembangan desa wisata berbasis unggulan. Putra \& Sutaguna (2020) menyelidiki persepsi masyarakat terhadap pengembangan Desa Penatahan sebagai desa wisata. Berbeda dengan pengabdian masyarakat yang sudah ada sebelumnya, penulis melakukan perancangan desain wisata Desa Jatisari dengan bentuk animasi.

Di kawasan Desa Jatisari, penduduknya masih memiliki tradisi dan budaya yang masih asli. Selain itu, beberapa faktor pendukung seperti makanan khas, sistem pertanian dan sistem sosial turut mewarnai sebuah kawasan desa wisata. Alam dan lingkungan yang masih asli dan terjaga merupakan salah satu faktor terpenting dari sebuah kawasan tujuan wisata (Tristaningrat, 2018; Yoeti, 1996).

Desa Jatisari adalah sebuah desa di wilayah Kecamatan Tajinan, Kabupaten Malang, Provinsi Jawa timur. Secara letak geografis wilayah Desa Jatisari terletak antara LS: 08o 03' 30" s/d 08o 04' 30" dan BT: 1120 39' 30 ', s/d 112041' 00', dengan luas $3.062 \mathrm{~km} 2$ dan dengan ketinggian $470 \mathrm{mdpl}$ yang memiliki suhu sekitar 25-30oC. Wilayah desa Jatisari memiliki kondisi lahan yang didominasi berupa persawahan dan pekarangan. Desa Jatisari berbatasan langsung dengan desa Randugading sebelah utara, desa Jambiarjo sebelah selatan, desa Purwosekar sebelah timur, dan desa Tangkil Sari sebelah barat. 
Dilihat dari lahan yang didominasi persawahan dan perkarangan, Desa Jatisari mempunyai potensi wisata yang sangat baik untuk dikembangkan untuk menjadi desa wisata. Salah satunya adalah Tanah Belong, merupakan lokasi yang berada di Desa Jatisari dengan luas tanah sekitar 5 hektar akan dikelola menjadi aset pendapatan desa. Belong memiliki potensi alam yang sangat baik dengan pemandangan di sekitar hamparan sawah yang asri. Hal ini menjadikan Belong sebagai potensi wisata yang dapat diolah dengan baik. Bapak kepala Desa Jatisari, perangkat desa, dan karang taruna bekerjasama untuk mengelola menjadikan wisata pemancingan ikan, wisata petik buah, wisata mini zoo, dan wisata kolam renang dengan harapan ada peningkatan pada sektor perekonomian warga Desa Jatisari.

Pengembangan potensi wisata menjadi salah satu program unggulan dalam kegiatan pengabdian kepada masyarakat yang dilakukan oleh mahasiswa Universitas Islam Negeri Maulana Malik Ibrahim Malang. Kegiatan ini meliputi pengembangan potensi wisata dengan perancangan desain berupa foto dan video animasi. Kontribusi pengabdian ini diharapkan masyarakat Desa Jatisari dapat terbantu untuk meningkatkan perekonomian masyarakat.

\section{METODE PENELITIAN}

Kegiatan pengabdian ini dilaksanakan oleh 15 mahasiswa UIN Maulana Malik Ibrahim Malang bersama dosen pendamping lapangan. Mahasiswa yang terlibat terdiri atas 10 perempuan dan 5 lakilaki. Sasaran pengabdian adalah warga Desa Jatisari, Kecamatan Tajinan, Kabupaten Malang. Metode pelaksanaan yang digunakan untuk kegiatan pengembangan wisata ini adalah survei lokasi dan perancangan desain wisata. Proses pembuatan desain menggunakan software SketchUp dan 3D Warehouse sebagai komponent materialnya. Waktu pelaksanaan pengabdian dilakukan mulai tanggal 29 Desember 2019 sampai tanggal 22 Januari 2020. Pelaksanaan pengabdian masyarakat ini dilakukan dengan beberapa kegiatan yang meliputi survei lokasi, kerja bakti, diskusi dan tanya jawab bersama perangkat desa dan karang taruna, tahap sosialisai, perancangan ukuran lokasi wisata. Tabel 1 menunjukan agenda dan bentuk kegiatan yang telah dilaksanakan untuk pengembangan wisata di Desa Jatisari.

Tabel 1: Agenda dan Bentuk Kegiatan untuk Pengembangan Wisata di Desa Jatisari

\begin{tabular}{|c|l|l|l|}
\hline No & \multicolumn{1}{|c|}{ Waktu } & \multicolumn{1}{|c|}{ Tempat } & \multicolumn{1}{|c|}{ Kegiatan } \\
\hline 1 & $\begin{array}{l}29 \\
\text { Desember } \\
2019\end{array}$ & Belong & $\begin{array}{l}\text { Survei Lokasi } \\
\text { Kerja Bakti }\end{array}$ \\
\hline 2 & $\begin{array}{l}\text { 2 Januari } \\
2020\end{array}$ & Posko & $\begin{array}{l}\text { Perancangan ukuran } \\
\text { lokasi wisata }\end{array}$ \\
\hline 3 & $\begin{array}{l}3 \text { Januari } \\
2020\end{array}$ & Balai Desa & $\begin{array}{l}\text { Diskusi dan tanya } \\
\text { jawab bersama } \\
\text { perangkat desa dan } \\
\text { karang taruna } \\
\text { mengenai fasilitas }\end{array}$ \\
\hline
\end{tabular}




\begin{tabular}{|c|l|l|l|}
\hline 6 Januari & & $\begin{array}{l}\text { yang akan disediakan } \\
\text { di lokasi wisata }\end{array}$ \\
\hline 4 & 2020 & $\begin{array}{l}\text { Perikanan, } \\
\text { Kepanjen }\end{array}$ & $\begin{array}{l}\text { Mencari informasi } \\
\text { mengenai pengadaan } \\
\text { bibit ikan }\end{array}$ \\
\hline 5 & $\begin{array}{l}8-15 \\
\text { Januari } \\
2020\end{array}$ & Posko & $\begin{array}{l}\text { Perancangan Desain } \\
\text { petik buah, Desain } \\
\text { Telaga, Desain Mini } \\
\text { Zoo, kolam } \\
\text { pemancingan, kolam } \\
\text { renang, Area makan, } \\
\text { mushola, parkir, dan } \\
\text { pencetakan poster }\end{array}$ \\
\hline 6 & $\begin{array}{l}\text { 22 Januari } \\
\text { 2020 }\end{array}$ & $\begin{array}{l}\text { Rumah } \\
\text { Bapak } \\
\text { Kepala } \\
\text { Desa }\end{array}$ & Laporan hasil desain \\
\hline & & \\
\hline
\end{tabular}

\section{HASIL DAN PEMBAHASAN}

Kegiatan pertama pada tanggal 29 Desember 2019, diawali dengan survei lokasi dan kegiatan kerja bakti bersama bapak-bapak Desa Jatisari untuk pembuatan saluran air. Setelah itu, pada tanggal 2 Januari 2020 pembuatan ukuran lokasi wisata menjadi 3D. Selanjutnya dilakukan tanya jawab dengan karang taruna lalu mendapatkan hasil bahwa fasilitas yang disediakan yaitu berupa petik buah, telaga, area parkir, mini zoo, area outbond, kolam pemancingan, kolam renang, tempat makan apung, musholla, dan toilet.

Pada tanggal 6 Januari 2020, kami mengunjungi dinas perikanan di Kepanjen, Kabupaten Malang. Kami bertanya mengenai alur pengadaan bibit ikan untuk di lokasi wisata. Setelah itu mendapat jawaban bahwa pengajuan proposal yang berisi ukuran kolam pemancingan, jenis ikan, dan perawatannya. Lalu kami bertanya tentang cara mengundang narasumber untuk sosialisai perawatan ikan di kolam pemancingan.
Mulai tanggal 8 Januari 2020 sampai 15 Januari 2020 adalah proses desain perancangan Wisata Belong. Dan diakhiri pada tanggal 22 Januari 2020, dengan presentasi pada kepala Desa Jatisari. Faktor pendukung yaitu area belong memiliki potensi wisata yang dapat dikembangkan untuk memajukan ekonomi warga Desa Jatisari, tetapi yang menghambat yaitu belum cairnya dana desa. Sehingga pembangunan dilakukan berangsurangsur. Untuk pengadaan bibit di lokasi belum terbangun kolam yang layak, karena perawatan ikan harus sampai jangka yang panjang.

Konsep Perancangan wisata berdasarkan beberapa aspek :

1. Pembangunan berwawasan lingkungan pada tapak, selain ditujukan sebagai wahana rekreasi, juga sebagai wahana pendidikan lingkungan bagi pengunjungnya. Agar kelestarian alam selalu terjaga serta termanfaatkan dengan baik. Lokasi yang dibangun, memperhatikan aspek konservasi dan lingkungan yang berkelanjutan.

2. Pembangunan untuk meningkatkan ekonomi warga Desa Jatisari. Dengan adanya wisata ini diharapkan dapat menambah keuntungan bagi desa dan warganya, selain menjadi potensi wisata juga menjadi potensi warga untuk membuka usaha di lokasi wisata 
Penataan layout wisata ini berdasarkan potensi yang ada, mulai dari area edukasi yang bisa menjadi sarana pembelajaran bagi pengunjungnya. Lalu area hiburan dan area bersantai yang dapat dimanfaatkan oleh pengunjung.

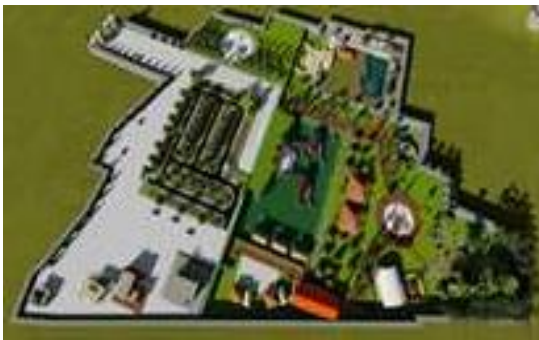

Gambar 1: Layout Plan Lokasi Wisata

Rencananya akan dibangun beberapa fasilitas untuk meningkatkan potensi Wisata Desa Jatisari. Penjelasan lebih detail disajikan pada bagian berikut.

\section{Area petik buah dan greenhouse}

Area petik buah ini terdiri dari 3 jenis tanaman stroberi, apel, dan jeruk. Rencananya pengunjung dapat menikmati buah-buahan dengan cara memetik sendiri, di bagain timur terdapat lahan kosong yang dapat dimanfaatkan warga sekitar untuk bertani. Ketika masuk ke area petik buah, pengunjung dapat melihat langsung greenhouse yang berada di tengah area petik buah. Nantinya buah-buah ini dapat dijual kembali oleh masyarakat.

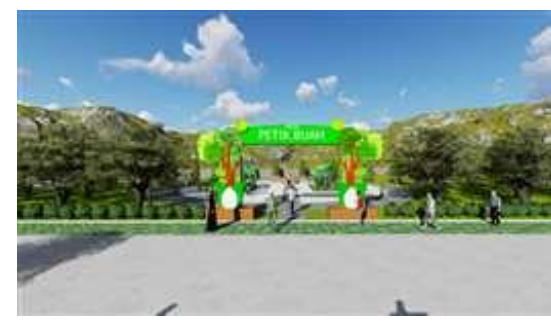

Gambar 2: Petik Buah

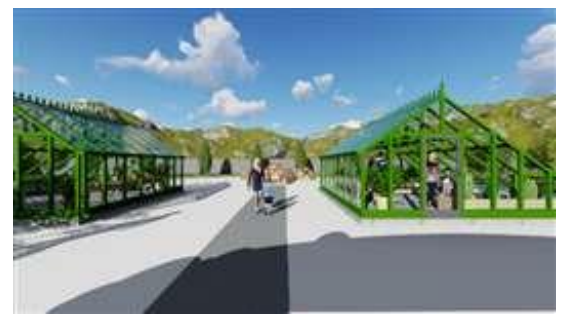

Gambar 3: Greenhouse

\section{Mini Zoo}

Di area kebun binatang ini terdapat beberapa jenis satwa yang diharapkan dapat mengedukasi pengunjung tentang satwa. Pengunjung juga dapat berinteraksi langsung dengan satwa yang berada di wisata ini.

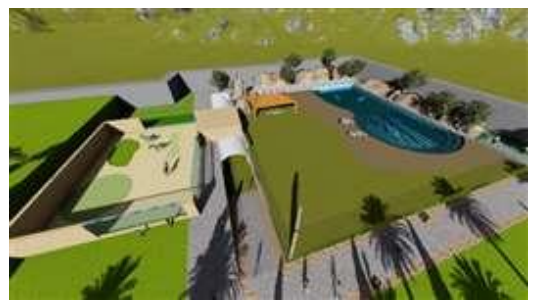

Gambar 4: Mini Zoo

\section{Kolam pemancingan}

Untuk kolam pemancingan ini disediakan untuk pengunjung anak-anak. Disediakan kolam yang dapat memudahkan dalam berkegiatan dan lebih aman untuk anak di bawah umur, sehingga dapat diawasi langsung oleh orangtua. 


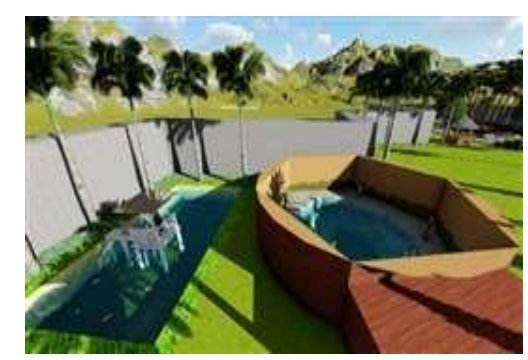

Gambar 5: Kolam Pemancingan

\section{Telaga}

Telaga ini berada di tengah lokasi wisata yang menjadi daya tarik pengunjung saat memasukinya. Pengunjung dapat menikmati fasilitas perahu yang disediakan. Telaga ini dikelilingi oleh pendopo, gazebo, dan tempat makan apung yang bisa diakses dengan menaiki perahu. Pendopo ini dimanfaatkan untuk tempat berkumpul yang bisa digunakan juga untuk masyarakat desa. Dan gazebo digunakan sebagai tempat bersantai sembari menikmati angin di tanah belong ini.

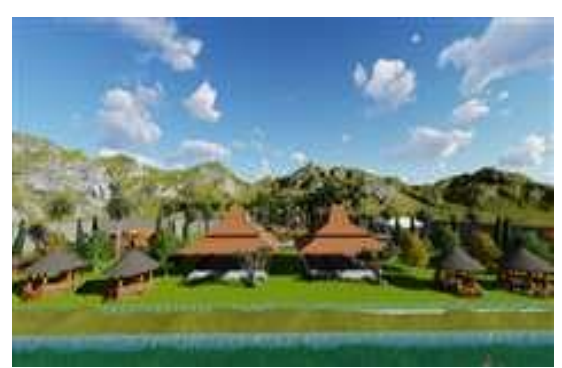

Gambar 6: Pendopo dan Gazebo

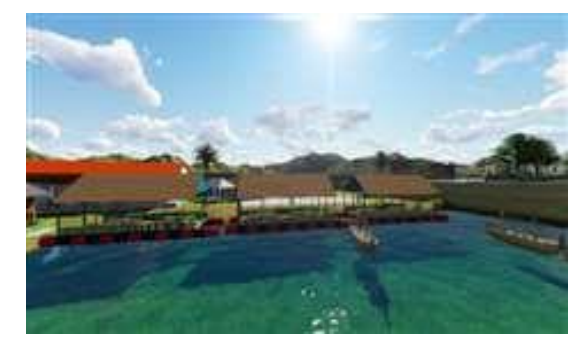

Gambar 7: Tempat Makan Apung

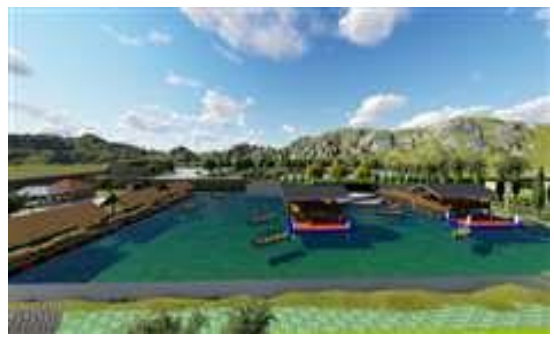

Gambar 8: Telaga

\section{Outbond}

Area outbond ini dilengkapi fasilitas flying fox, playground yang dapat mendukung aktivitas para pengunjung. Di sekitar area outbond juga terdapat gazebo sebagai tempat menunggu dan bersantai.

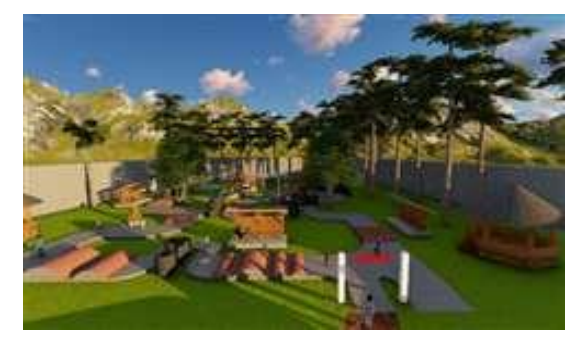

Gambar 9: Area Outbond

\section{Kolam Renang}

Terdapat dua kolam renang yang disediakan pada lokasi ini yaitu ,kolam renang dewasa dan anak. Terdapat fasilitas permainan air di dalam kolam, yaitu seluncuran. 

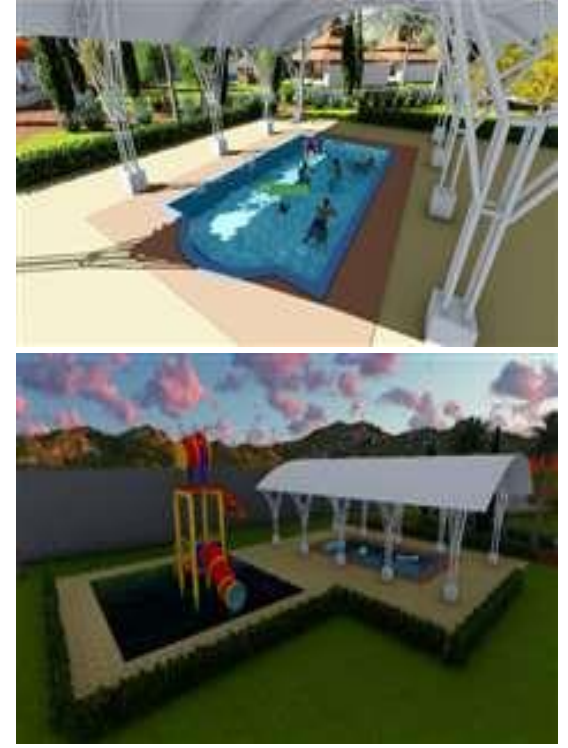

Gambar 10: Kolam Renang

\section{Playground}

Playground ini berada di bagian tengah antara kolam renang dan area outbond, fungsinya sebagai area transisi dan sebagai tempat permainan ketika pengunjung jenuh. Playground ini disediakan untuk anak-anak.

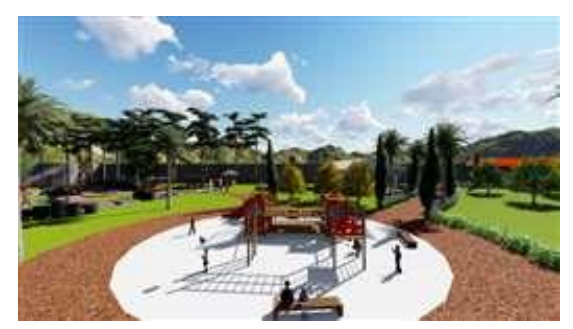

Gambar 11: Playground

\section{Area bersantai}

Setelah pengunjung selesai menikmati wisata ini, pengunjung dapat berisitirahat sambil menikmati pemandangan telaga lewat area bersantai. Di dalam area bersantai dilengkapi fasilitas yaitu sofa dan meja. Ddi depan area bersantai terdapat tempat lapang yang dapat dimanfaatkan untuk tempat berkegiatan.

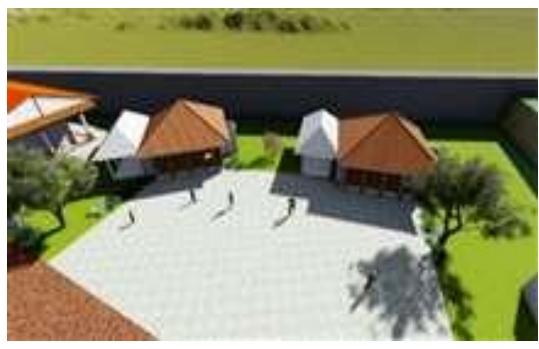

Gambar 12: Area Bersantai

\section{Area makan}

Setelah lelah berjalan-jalan pengunjung dapat menikmati kuliner yang ada di tempat wisata. Pengunjung dapat menikmati kuliner khas desa ini dengan pemandangan seluruh area wisata dan menikmati angin-angin di lokasi ini.

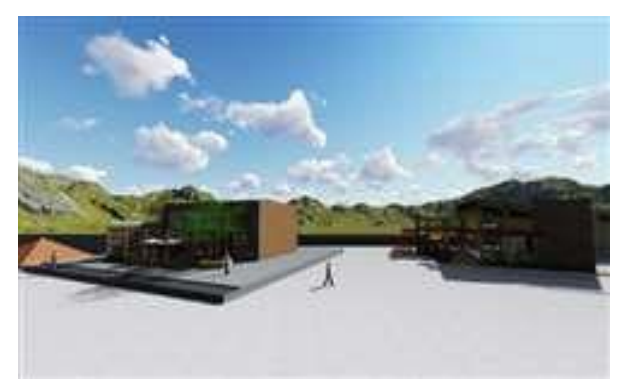

Gambar 13: Area Makan

\section{Fasilitas penunjang}

Fasilitas penunjang yaitu berupa musholla dan toilet, di tempat ini disediakan toilet yang berada di dekat tempat hiburan dan musholla berada di area yang mudah di akses, yaitu akses keluar dan masuk wisata. 


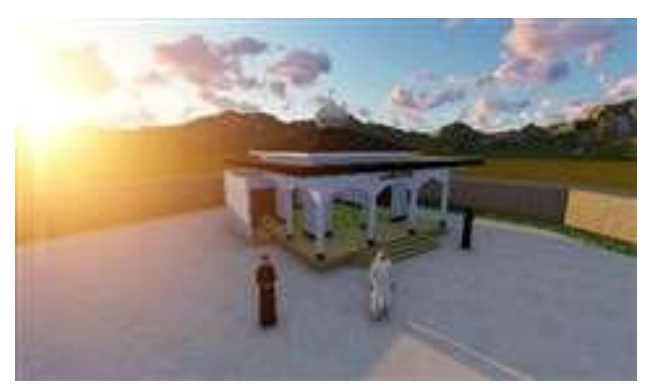

Gambar 14: Musholla

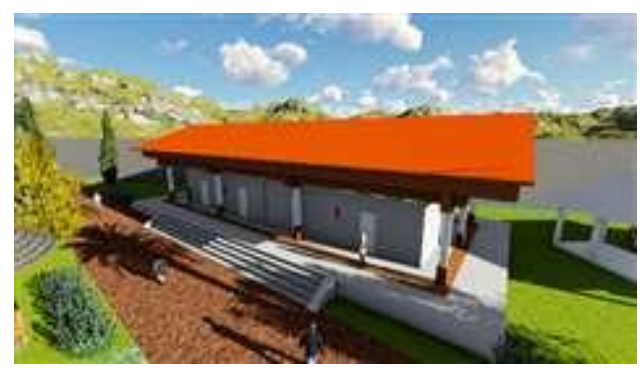

Gambar 15: Toilet

\section{SIMPULAN}

Hasil kegiatan ini berupa rancangan desain area petik buah, greenhouse mini zoo, kolam pemancingan, telaga, outbond, kolam renang, area bersantai, playground, dan fasilitas penunjang. Penggalian informasi dari warga desa pun disambut dengan baik dan menambah semangat warga untuk menjadikan Desa Jatisari sebagai desa wisata. Hasil desain Wisata Belong dapat membantu untuk pembangunan walaupun dilakukan secara bertahap. Kegiatan pengabdian selanjutnya dapat dilakukan untuk pengadaan bibit ikan dari Dinas Kelautan dan Perikanan Kabupaten Malang dan sosialisasi terkait perawatan ikan yang disediakan di Desa Jatisari.

\section{DAFTAR PUSTAKA}

Atmoko, T. P. H. 2014. Strategi Pengembangan Potensi Desa Wisata Brajan Kabupaten Sleman. Jurnal Ilmiah Akademi Pariwisata Yogyakarta, 12(2) 146-154.

Fikri, Z., \& Septiawan, Y. 2020. Pemanfaatan Dana Desa dalam Pengembangan Desa Wisata di Desa Kurau Barat. Publicio: Jurnal Ilmiah Politik, Kebijakan dan Sosial, 2(1), 24-32.

Purwanto, R. 2020. Pengembangan Desa Wisata Berbasis Unggulan dan Pemberdayaan Masyarakat. Public Service and Governance Journal, 1(1), 112-133.

Putra, A. M., \& Sutaguna, I. N. T. 2020. Persepsi Masyarakat Desa Penatahan Terhadap Dikembangkannya Desa Penatahan Sebagai Desa Wisata di Kecamatan Penebel, Kabupaten Tabanan. Sekolah Tinggi Pariwisata Triatma Jaya, 9(2), 219-239.

Raharja, S. U. J., Marbun, M., \& Chan, A. 2019. Strategi Pengembangan Pariwisata Perdesaan di Lebak Muncang, Bandung-Jawa Barat. Sosiohumaniora, 21(2), 159-165.

Ratnaningtyas, Y. A., \& Widyasmoro, A. 2016. Pemasaran Desa Wisata Kalibuntung dalam Mendukung Pengembangan 
Pariwisata di Kabupaten

Bantul. Jurnal kepariwisataan

Indonesia, 11(1), 1-24.

Saepudin, E., Budiono, A., \& Halimah, 2019. Pengembangan Desa Wisata Pendidikan Di Desa Cibodas Kabupaten Bandung Barat. Sosiohumaniora, 21(1), 1-10.

Sumarto, R. H., \& Dwiantara, L. $2020 . \quad$ Pemberdayaan Masyarakat dalam Tata Kelola Pariwisata Di Kampung Wisata Dewo Bronto Yogyakarta. Journal Publicuho, 2(4), 111-127.

Tristaningrat, M. A. N. 2018. Gagasan Pengembangan Desa Wisata Berbasis Budaya Lokal Daerah untuk Mengembangkan Kearifan Lokal Daerah. Maha Widya Bhuwana: Jurnal Pendidikan, Agama dan Budaya, 1(1), 8189.

Wiyatiningsih, S., Harijani, W. S., Santoso, W., \& Wijaya, R. S. 2020. Persepsi Masyarakat Terhadap Upaya Pengembangan Desa Wisata Jeruk Pamelo Organik di Desa Tambakmas, Kecamatan Sukomoro, Kabupaten Magetan. Jurnal Abadimas Adi Buana, 3(2), 23-36.

Yoeti, O. A. 1996. Pengantar Ilmu Pariwisata. Bandung: Angkasa.

Zakaria, F., \& Suprihardjo, R. 2014.

Konsep Pengembangan
Kawasan Desa Wisata di Desa Bandungan Kecamatan Pakong Kabupaten Pamekasan. Jurnal Teknik ITS, 3(2), C245-C249. 